\title{
Comparison of measured and estimated permeability for artificially prepared coarse-grained soil samples
}

Rudarsko-geološko-naftni zbornik

(The Mining-Geology-Petroleum Engineering Bulletin) UDC: 622.1

DOI: $10.17794 /$ rgn.2021.3.12

Preliminary communication

\author{
Patricia Živković́; ; Mirela Burečić Šafran ${ }^{2}$; Biljana Kovačević Zelić3 \\ ${ }^{1}$ Croatian Geological Survey, Sachsova 2, 10000 Zagreb, Croatia \\ ${ }^{2}$ Pikli 3, 10000 Zagreb, Croatia \\ ${ }^{3}$ University of Zagreb, Faculty of Mining, Geology and Petroleum Engineering, Pierottijeva 6, 10000 Zagreb, Croatia
}

\begin{abstract}
Knowledge about soil permeability is important in various scientific fields: hydrology and hydrogeology, geotechnics, environmental geotechnics, and others. Depending on the different goals that need to be achieved by a particular engineering project, the conditions in which the permeability coefficient is determined in terms of applied hydraulic gradients, applied stresses, type of test fluid, etc. are adjusted, as well as the required precision of its determination. In addition, the permeability coefficient is a soil property with the largest range of possible values. It can be determined through various laboratory and field methods, and by applying established empirical correlations using data on the grain-size distribution and empirical coefficients that depend on some factors, such as hydraulic radius (specific surface), curvature, porosity, etc. This paper presents the results of laboratory testing of the permeability coefficient by the constant head test and the use of a permeameter. The results were compared with the permeability coefficient obtained by applying a number of empirical correlations. Artificial samples were prepared in the laboratory by mixing different previously prepared soil fractions in order to determine the influence of particle size and soil gradation on the estimated soil permeability coefficient.
\end{abstract}

\section{Keywords:}

permeability coefficient, permeameter, constant head test, empirical correlations

\section{Introduction}

The permeability coefficient is an important design parameter in the case of designing and constructing numerous geotechnical and hydrotechnical facilities. Thus, for example, the water in a soil affects the soil's physical and mechanical properties, and consequently, all the types of geotechnical structures that are made in the soil. Knowledge about soil permeability is important for estimating slope stability, water inflow into excavation pits, volumetric change (swelling) in the soil, settlement and consolidation calculations and many other problems. In environmental geotechnics, knowledge of soil permeability is important for constructing hydraulic barriers or cleaning contaminated sites, in which case soil permeability not only has to be determined with greater precision, but also with different test fluids, both miscible and immiscible (Kovačević Zelić et al., 2007; Domitrović et al., 2012; Skrzeczkowska \& Pietrzykowski, 2012). For hydrogeological research and the designing of dams, embankments and water barriers, knowledge of the permeability coefficient is important, for example, for the

Corresponding author: Biljana Kovačević Zelić bkzelic@rgn.hr estimation of the quantity of water that can be drawn from aquifers, design and construction of the facilities related to water supply (i.e. water wells), the planning of the irrigation systems and groundwater protection areas, etc. (Ružičić et al., 2012; Ružičić et al., 2018).

Given the different goals to be achieved by a particular engineering project, it is obvious that the permeability coefficient does not have to be determined with the same level of precision, nor are the conditions identical under which it is determined in terms of applied hydraulic gradients, applied stresses, type of test fluid, etc. It is also important to point out that the permeability coefficient is a property of soil with the largest range of possible values. Thus, the permeability of gravel and clay can differ over a million times, and even for the same type of soil, it can vary more than one order of magnitude.

In view of the above, the soil permeability coefficient is determined by various methods: a) laboratory tests using the constant head method, falling head method or flow pump test, b) field measurements - such as the well pumping test, c) applying known empirical correlations by using data on the grain-size distribution of the porous medium (Veinović et al., 2003; Petrinjek et al., 2018). All of the above methods for determining the permeability coefficient have certain limitations, advantages and disad- 
vantages, and depending on the importance of the facility, the range of expected values and the required accuracy, one or more methods are selected for its determination. To avoid possible negative consequences, it is desirable to estimate or determine the soil permeability coefficient using several different methods, and through good engineering judgment, more safely determine its numerical value that will be used in the designing of hydrogeological, hydrotechnical or geotechnical constructions.

According to Posavec et al. (2018), in different scientific fields dealing with groundwater research, it is possible to use the terms hydraulic conductivity or permeability coefficient. The most commonly used terms in hydrogeological literature and practice today are hydraulic conductivity, $K[\mathrm{~L} / \mathrm{T}](\mathrm{m} / \mathrm{s}$ in the SI system) or permeability coefficient, $k[\mathrm{~L} / \mathrm{T}](\mathrm{m} / \mathrm{s}$ in the SI system), which are specifically used to denote a single-phase water flow through a porous medium. In geotechnical engineering, the term permeability coefficient (or water permeability, marked $k[\mathrm{~L} / \mathrm{T}](\mathrm{m} / \mathrm{s}$ in the SI system) is used. The term permeability, although denoted by the same symbol, $k$ $\left[\mathrm{L}^{2}\right]\left(\mathrm{m}^{2}\right.$ in the SI system), in hydrogeology represents the internal, absolute or specific permeability, referring to a porous medium which is completely saturated with a single-phase fluid, i.e. water in the case under consideration, and is exclusively a characteristic of the porous medium, not the fluid. In geotechnical engineering, the internal or intrinsic permeability is denoted with the symbol $K\left[\mathrm{~L}^{2}\right]\left(\mathrm{m}^{2}\right.$ in the SI system). Hydraulic conductivity refers to the capacity of the porous medium to conduct water, and permeability refers to the capacity of the porous medium to conduct any fluid. Due to the different terms and symbols in various fields of engineering, in this article, the term permeability coefficient (or water permeability) and the symbol $k$, [L/T] $(\mathrm{m} / \mathrm{s}$ in the SI system) will be used hereinafter, which is almost exclusively used in geotechnical engineering, and is also acceptable in other scientific fields.

In this paper, the results of constant head permeameter tests are presented, which were compared with the permeability coefficient obtained by a number of empirical correlations. For all tests, artificial samples were prepared in the laboratory by mixing different previously prepared soil fractions, in order to determine the influence of soil gradation and particle size (of effective and maximum grain diameter) on the estimated permeability coefficient.

\section{Theoretical consideration}

\subsection{Darcy's law - the linear law of filtration}

The basic law describing gravitational water flow in a porous medium was empirically established by the French engineer Henry Darcy (1865). The Darcy device had the shape of a cylindrical tube filled with the tested porous material (sand), which is shown in Figure 1.

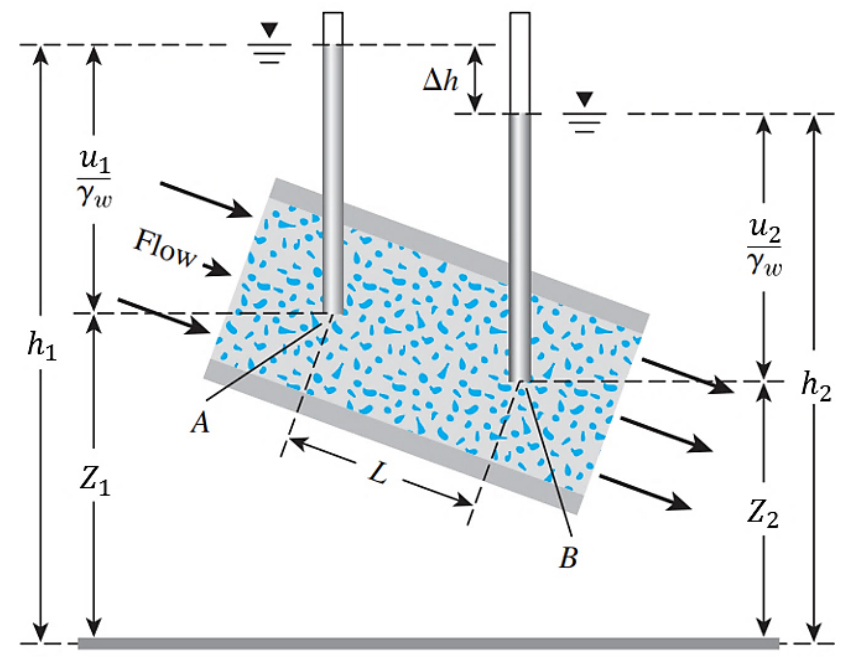

Figure 1: Schematic presentation of Darcy's device

(Das, 2010)

Darcy added water to the surface of the porous medium, thus maintaining a constant level. At the bottom was a mesh through which the filtered water flowed into the beaker.

The quantity of water $(Q)$ flowing through the sample is proportional to the difference of the potential $\left(h_{1}-h_{2}\right)$ and the cross-sectional area of the sample $(A)$, and is inversely proportional to the length of the sample $(L)$. It is defined by the following Equation 1:

$$
Q=k \cdot A \cdot \frac{h_{1}-h_{2}}{L}=k \cdot A \cdot i
$$

where:

$Q \quad$ - the quantity of water flowing through the porous material; flow $\left(\mathrm{m}^{3} / \mathrm{s}\right)$,

A - cross-sectional area perpendicular to the flow direction $\left(\mathrm{m}^{2}\right)$,

$k-$ proportionality factor or permeability coefficient $(\mathrm{m} / \mathrm{s})$

$h_{l}, h_{2}$ - water heights (potentials) above the datum measured by manometers at the inlet and outlet of the porous medium $(\mathrm{m})$,

$i \quad$ - hydraulic gradient (dimensionless value), loss of mechanical energy of fluid (water) along the flow or head loss on the observed path,

$L \quad$ - sample length (m).

Permeability is a function not only of the porous medium, but also of the fluid. For real soils, permeability is influenced by particle size, void ratio, composition, fabric and degree of saturation (Preene, 2019). In the Kozeny-Carman equation, for example, only the particle size and void ratio are directly included, while the other parameters are treated indirectly (Lambe \& Whitman, 1979).

The flow of water through the sample at low velocities is defined by Darcy's linear law. If the velocity of 


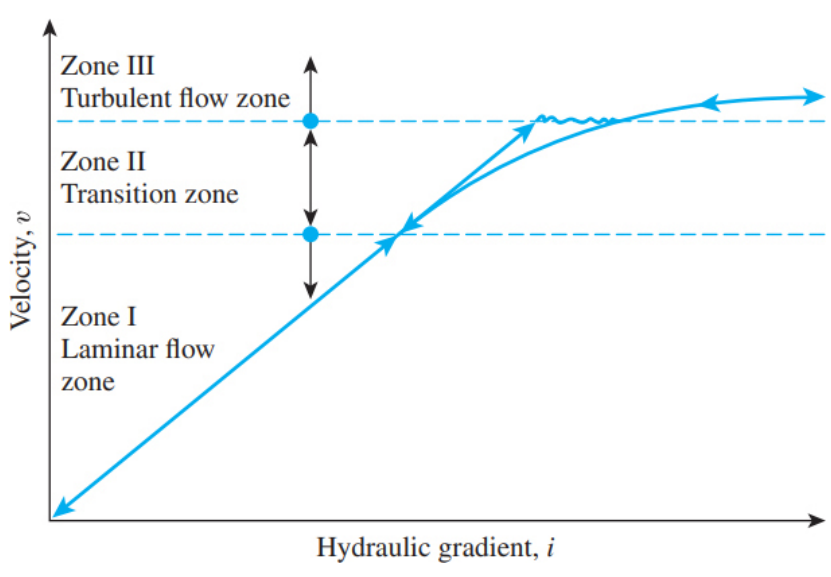

Figure 2: Change of the flow regime depending on the hydraulic gradient (Das, 2010)

water through the sample increases, the flow changes from laminar linear flow to laminar non-linear flow, and if that velocity is even higher, it changes to turbulent flow. In Figure 2 (Das, 2010) three flow regimes are presented: zone I (laminar flow), zone II (transition zone) and zone III (turbulent flow). Since the flow of water through the soil is connected to velocity (Urumović, 2003), it can be stated that the permeability coefficient has a velocity dimension, and its values are expressed in $\mathrm{m} / \mathrm{s}$.

In zone I, the flow velocity $v$ linearly depends on the hydraulic gradient. With larger hydraulic gradients, the water flow becomes turbulent (zone III), when the velocity/gradient ratio is no longer linear (Das, 2010). The permeability coefficient is determined at low gradients (zone I), which need to be achieved during the tests of the material, and is defined as the quantity of water flowing through the cross-section of the aquifer rock/soil unit area $\left(\mathrm{F}=1 \mathrm{~m}^{2}\right)$ with the unit hydraulic gradient, i.e. head loss of $1 \mathrm{~m}$ at a distance of $1 \mathrm{~m}$ in the direction of groundwater flow (dimension L/T, e.g. $\mathrm{m} / \mathrm{s}, \mathrm{m} / \mathrm{day}, \mathrm{cm} / \mathrm{s}$ ) (Bačani, 2006). In the case of turbulent flow, Darcy's law is invalid.

\subsection{Laboratory methods for determining the permeability coefficient}

There are several methods for determining the permeability coefficient by laboratory procedures, as already described in the introduction. In practical engineering, one of the most commonly used laboratory methods for the determination of gas or fluid permeability for coarsegrained soil samples is using a permeameter. Laboratory tests have certain advantages, because they are performed under controlled conditions and the results can be obtained fairly quickly. Generally speaking, in all laboratory methods, there is the problem of sample representativeness, and for fine-grained soils, it is also necessary to have more expensive and sophisticated equipment in order to determine the permeability relatively quickly.

\subsection{Empirical correlations}

It is generally known that coarse-grained soils have higher permeability than fine-grained soils. However, the permeability of coarse-grained soils with an increased content of fine particles (according to some authors, $30 \%$ or more) can also be significantly reduced (Boadu, 2000). In pure coarse-grained soils, the permeability increases with grain size, which indicates the possibility of linking the permeability coefficient with the characteristic grain diameters obtained from the grainsize distribution of the soil (Salarashayeri, 2012). Based on numerous hydrogeological studies, Freeze and Cherry (cited in Shepherd 1989) concluded that the permeability of granular porous media is associated with the distribution of grains, but also with many other properties such as particle shape and angularity/roundness, and their mutual distribution, which has not yet been quantified in detail. Summers and Weber (cited in Shepherd 1989) also addressed this issue and noted that data were insufficient, especially for mixtures of clay, gravel, and sand (e.g. glacial deposits). Despite this, in solving hydrogeological and geotechnical problems, designers are often asked to estimate soil permeability based only on the analysis of its grain-size composition. The estimated permeability coefficient is further used for both groundwater flow modelling in the soil, and for modelling the transport of water-soluble pollutants or in various geotechnical calculations. In hydrogeology, reliable techniques for determining the permeability coefficient of aquifers are required for improving the management and preservation of groundwater. Modern approaches to solving problems in geotechnical engineering also require a more reliable determination of soil hydraulic properties, rather than just an estimation of permeability coefficients based on average grain size or grain-size distribution (Shepherd, 1989).

Alternatively, methods of estimating the permeability coefficient from empirical formulas based on the characteristics of the grain-size distribution, i.e. the grain-size composition of the soil are used. Although in hydromechanics, it would be more useful to characterize pore diameters rather than grain diameters, it is very difficult to determine the distribution of pore size, so the approximation of hydraulic properties is mainly based on grain size, which is much easier to measure (Cirpka, 2003). Numerous scientists have studied this inter-relatedness and several correlations have been obtained based on experimental work. The first known correlation is the Hazen correlation, dating back to the 19th century (Hazen, 1892). Kozeny proposed an equation modified by Carman, which is known today as the Kozeny-Carman equation. Other well-known empirical equations were derived by Terzaghi (1925) and Peck, Shepherd (1989), Alyamani and Sen (1993), Slichter (1899) and many others. The applicability of these correlations depends on the type of soil for which the permeability coefficient is determined. Vuković and Soro (1992) observed that the application of different empirical formulas for the 
same material can render different values of the permeability coefficient, with a factor of 10 to even up to 20 .

In this paper, empirical equations were used to estimate the permeability coefficient, for which the applicability conditions were fulfilled on the basis of the analysis of the grain size distribution of the tested material. The properties of the test fluid, i.e. water at a temperature of $20^{\circ} \mathrm{C}$, were taken into account when estimating the permeability coefficient. Soil porosity, $n$ has a significant effect on permeability. In empirical equations (Odong 2007, according to Vuković and Soro, 1992), the following Equation $\mathbf{2}$ is used to calculate porosity:

where:

$$
n=0.255\left(1+0.83^{C_{u}}\right)
$$

$n$ - soil porosity,

$C_{u}$ - uniformity coefficient, calculated from the grainsize distribution curve $\left(\frac{\mathrm{d}_{60}}{\mathrm{~d}_{10}}\right)$,

$d_{60}$ - characteristic grain diameter at $60 \%$ passing $(\mathrm{mm})$, $d_{10}$ - characteristic grain diameter at $10 \%$ passing $(\mathrm{mm})$.
According to Vuković and Soro (1992), the general Equation 3 for the permeability coefficient $(\mathrm{m} / \mathrm{s})$ is:

$$
k=\frac{\mathrm{g}}{v} \cdot \mathrm{C} \cdot[\mathrm{f}(\mathrm{n})] \cdot d_{e}^{2}
$$

where:

$g-$ acceleration of gravity $\left(\mathrm{m} / \mathrm{s}^{2}\right)$,

$v \quad$ - dynamic viscosity of water $\left(\mathrm{m}^{2} / \mathrm{s}\right)$,

$C$ - dimensionless coefficient of proportionality, the value of which depends not only on the type of the observed porous medium, but also on how the effect of hydraulic radius (specific surface), curvature and porosity is expressed,

$f(n)$ - porosity function,

$d_{e}$ - effective grain diameter ( $\mathrm{mm}$ ).

Based on the above general Equation 3, in Table 1 several ways of calculating the permeability coefficient according to the mentioned authors are presented. For each empirical equation, the application area is defined as well, which must first be fulfilled.

\begin{tabular}{|c|c|c|c|c|}
\hline Author & Value $C$ & Porosity function $n$ & $\begin{array}{l}\text { Effective grain } \\
\text { diameter } d_{e}\end{array}$ & Domain of applicability \\
\hline $\begin{array}{l}\text { Alyamani and Sen } \\
\text { (Odong, 2007) }\end{array}$ & 1300 & 1.0 & {$\left[I_{\mathrm{o}}+0.025\left(d_{50}-d_{10}\right)\right]$} & not defined \\
\hline $\begin{array}{l}\text { Barr } \\
\text { (Devlin, 2015) }\end{array}$ & $\begin{array}{l}\frac{1}{(36) 5 \cdot \mathrm{C}_{\mathrm{s}}^{2}} \\
\mathrm{C}_{\mathrm{s}}^{2}: 1 \text { for spherical grains } \\
\mathrm{C}_{\mathrm{s}}^{2}: 1.35 \text { for angular grains }\end{array}$ & $\frac{n^{3}}{(1-n)^{2}}$ & $d_{10}$ & not defined \\
\hline $\begin{array}{l}\text { Beyer } \\
\text { (Odong, 2007) }\end{array}$ & $6.00 \cdot 10^{-4} \log \frac{500}{C_{u}}$ & 1 & $d_{10}$ & $\begin{array}{l}0.06 \mathrm{~mm}<\mathrm{d}_{10}<0.6 \mathrm{~mm} \\
1<\mathrm{C}_{\mathrm{u}}<20\end{array}$ \\
\hline $\begin{array}{l}\text { Chapuis } \\
\text { (̌̌íha, 2018) }\end{array}$ & 1219.9 & $\frac{\mathrm{n}^{2.3475}}{(1-\mathrm{n})^{1.565}}$ & $\mathrm{~d}_{10}^{1.565}$ & $0.03 \mathrm{~mm}<\mathrm{d}_{10}<3 \mathrm{~mm}$ \\
\hline $\begin{array}{l}\text { Hazen } \\
\text { (Odong, 2007) }\end{array}$ & $6.00 \cdot 10^{-4}$ & {$[1+10(\mathrm{n}-0.26)]$} & $d_{10}$ & $\begin{array}{l}0.1 \mathrm{~mm}<\mathrm{d}_{10}<3 \mathrm{~mm} \\
\mathrm{C}<5\end{array}$ \\
\hline $\begin{array}{l}\text { Kozeny - Carman } \\
\text { (Odong, 2007) }\end{array}$ & $8.30 \cdot 10^{-3}$ & $\frac{n^{3}}{1-n}$ & $d_{10}$ & $\mathrm{~d}_{10}<3 \mathrm{~mm}$ \\
\hline 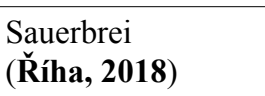 & $3.75 \cdot 10^{-3}$ & $\frac{n^{3}}{(1-n)^{2}}$ & $d_{17}$ & $\begin{array}{l}\text { Sand and sandy clay. } \\
\mathrm{d}<0.5 \mathrm{~mm}\end{array}$ \\
\hline $\begin{array}{l}\text { Seelheim } \\
\text { (ríha, 2018) }\end{array}$ & $3.57 \cdot 10^{-3}$ & 1 & $d_{50}$ & Sand and clay \\
\hline $\begin{array}{l}\text { Slichter } \\
\text { (Odong, 2007) }\end{array}$ & $1.00 \cdot 10^{-2}$ & $n^{3.287}$ & $d_{10}$ & $0.1 \mathrm{~mm}<\mathrm{d}_{10}<5 \mathrm{~mm}$ \\
\hline $\begin{array}{l}\text { Terzagi } \\
\text { (Odong, 2007) }\end{array}$ & $\begin{array}{l}10.70 \cdot 10^{-3(1)} \\
6.10 \cdot 10^{-3(2)}\end{array}$ & $\left(\frac{n-0.13}{\sqrt[3]{1-n}}\right)^{2}$ & $d_{10}$ & $\begin{array}{l}\text { Coarse sand with rounded }{ }^{(1)} \\
\text { to angular grains }{ }^{(2)}\end{array}$ \\
\hline $\begin{array}{l}\text { USBR } \\
\text { (Odong, 2007) }\end{array}$ & $4.80 \cdot 10^{-4}$ & 1 & $d_{20}$ & $\begin{array}{l}\mathrm{C}_{\mathrm{u}}<5 \\
\text { Medium grained sand }\end{array}$ \\
\hline
\end{tabular}

Table 1. Empirical equations for determining the permeability coefficient

where:

$\mathrm{d}_{10}$ - characteristic grain diameter at $10 \%$ passing $(\mathrm{mm})$, $d_{17}$ - characteristic grain diameter at $17 \%$ passing $(\mathrm{mm})$, $d_{20}$ - characteristic grain diameter at $20 \%$ passing $(\mathrm{mm})$, $d_{50}$ - characteristic grain diameter at $50 \%$ passing $(\mathrm{mm})$,
$C_{u}$ - uniformity coefficient, calculated from the properties of the grain-size distribution curve $\left(\frac{\mathrm{d}_{60}}{\mathrm{~d}_{10}}\right)$,

$I_{o}-$ is the intercept (in $\mathrm{mm}$ ) of the line formed by $\mathrm{d}_{50}$ and $\mathrm{d}_{10}$ with the grain-size axis, $d_{10}$ is the effective grain diameter $(\mathrm{mm})$, and $\mathrm{d}_{50}$ is the median grain diameter (mm) (Odong, 2007). 
Figure 3: Grain-size distribution curves with measured permeabilities (Živković, 2020)

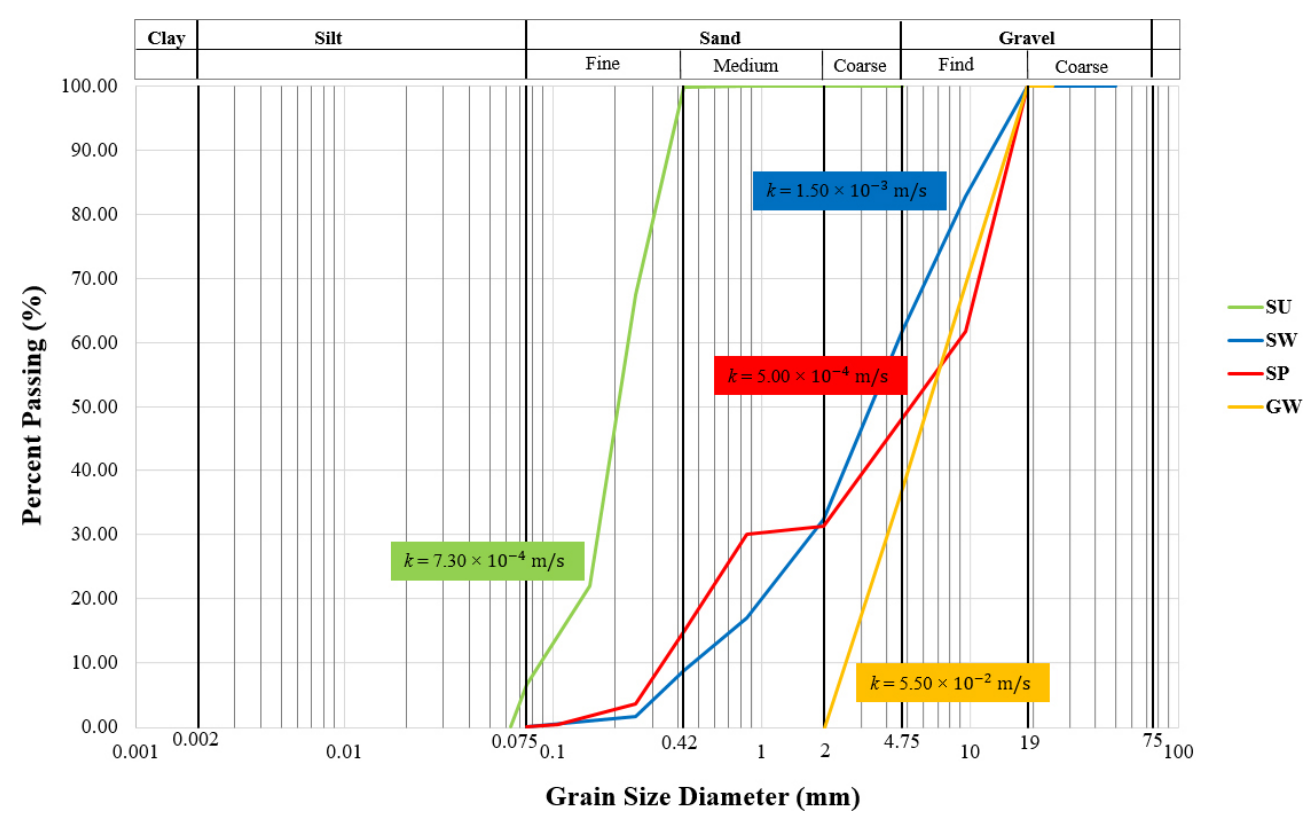

Table 2: Soil sample characteristics

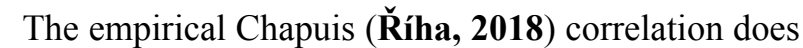
not take into consideration the influence of gravity and dynamic viscosity of water, nor is the value of the effective grain diameter a squared value. This correlation is valid for samples where the value of $d_{10}$ is greater than $0.03 \mathrm{~mm}$ and less than $3 \mathrm{~mm}$.

\section{Materials and methods}

\subsection{Test samples}

The permeability coefficient test was performed on four test samples, which were artificially prepared in the laboratory by a combination of different fractions of natural soil samples in order to determine the influence of particle size and soil gradation on permeability. The grain-size distribution of the samples was determined by sieving according to the ASTM standard: D6913/ D6913M - 17. Those artificially prepared samples were later placed into the testing cell and constant head permeameter tests were conducted. One sample of uniformly graded sand was prepared (see Figure 3, designation $\mathrm{SU}$ ), as well as three samples of gravel: well, poorly and uniformly graded (see Figure 3, designations GW, GP and GU) according to Unified Soil Classification System (USCS), European Soil Classification System (ESCS), and standard practice in Croatia (Nonveiller, 1979).

Grain-size distribution curves were used as input data to determine the soil parameters (e.g. effective grain diameter, uniformity coefficient $\mathrm{Cu}$, and coefficient of curvature $\mathrm{Cc}$ ), which were then used to calculate the permeability coefficient by empirical correlations.

\subsection{Characterization of samples based on grain- size distribution curves}

Grain-size distribution curves represent the input data for defining the parameters required to estimate the per-

\begin{tabular}{|l|l|l|l|l|}
\hline $\begin{array}{l}\text { Samples/ } \\
\text { Parameters }\end{array}$ & SU & GU & GW & GP \\
\hline $\mathrm{e}$ & 0.70 & 0.67 & 0.43 & 0.35 \\
\hline $\mathrm{n}$ & 0.41 & 0.40 & 0.30 & 0.26 \\
\hline $\mathrm{D}_{10}(\mathrm{~mm})$ & 0.09 & 2.74 & 0.48 & 0.35 \\
\hline $\mathrm{D}_{17}(\mathrm{~mm})$ & 0.12 & 3.17 & 0.84 & 0.48 \\
\hline $\mathrm{D}_{20}(\mathrm{~mm})$ & 0.13 & 3.48 & 1.00 & 0.57 \\
\hline $\mathrm{D}_{30}(\mathrm{~mm})$ & 0.17 & 4.22 & 1.82 & 0.85 \\
\hline $\mathrm{D}_{50}(\mathrm{~mm})$ & 0.21 & 6.33 & 3.64 & 6.61 \\
\hline $\mathrm{D}_{60}(\mathrm{~mm})$ & 0.23 & 8.16 & 4.57 & 9.08 \\
\hline $\mathrm{I}_{\mathrm{o}}(\mathrm{mm})$ & 0.07 & 2.00 & 0.30 & 0.17 \\
\hline $\mathrm{C}_{\mathrm{u}}(-)$ & 2.56 & 2.98 & 9.46 & 26.0 \\
\hline $\mathrm{C}_{\mathrm{c}}(-)$ & 1.32 & 0.80 & 1.50 & 0.23 \\
\hline
\end{tabular}

meability coefficient. For each of the four test samples the effective grain diameters $\mathrm{D}_{10}, \mathrm{D}_{17}, \mathrm{D}_{20}, \mathrm{D}_{30}, \mathrm{D}_{50}$ and $\mathrm{D}_{60}$, uniformity coefficient, $\mathrm{C}_{\mathrm{u}}$ and coefficient of curvature $\mathrm{C}_{\mathrm{c}}$ were determined. These parameters were used in defining the conditions, i.e. the domain of applicability and the calculation of the permeability coefficient by empirical correlations. The above-mentioned parameters, along with the void ratio and porosity of four test samples, are shown in Table 2. Porosity was determined by calculation and those values were used for the determination of the permeability coefficients by empirical correlations.

Samples prepared in this way make it possible to examine the influence of gravel gradation on the permeability coefficient by comparing the results for samples denoted with GU, GW and GP. Moreover, the sample of uniformly graded sand (SU) shows the influence of particle size (maximum and effective grain diameter) on 


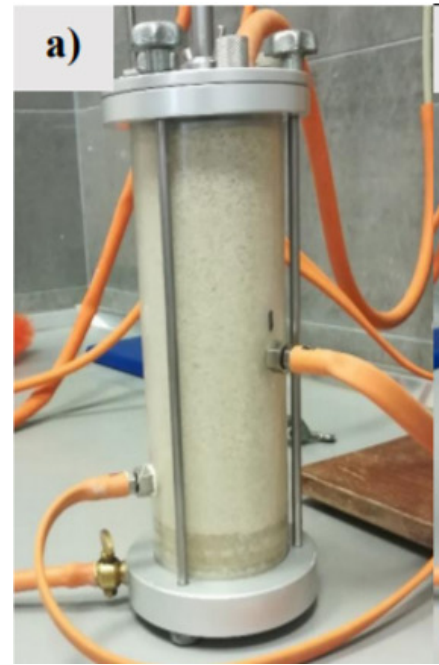

(a) sample SU

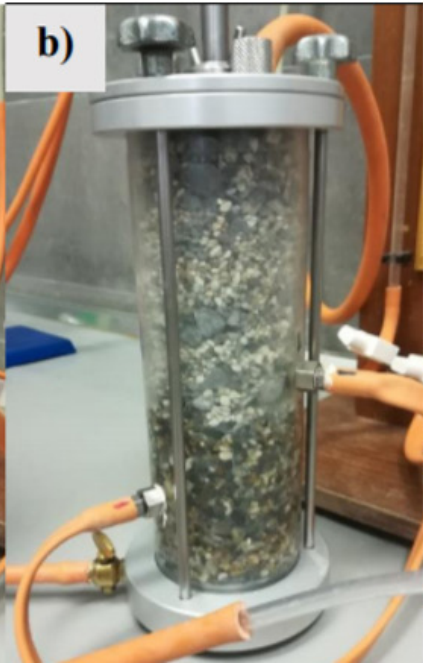

(b) sample GU

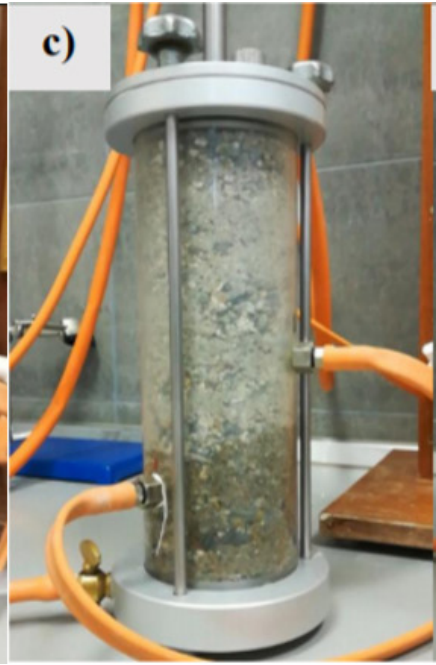

(c) sample GW d)

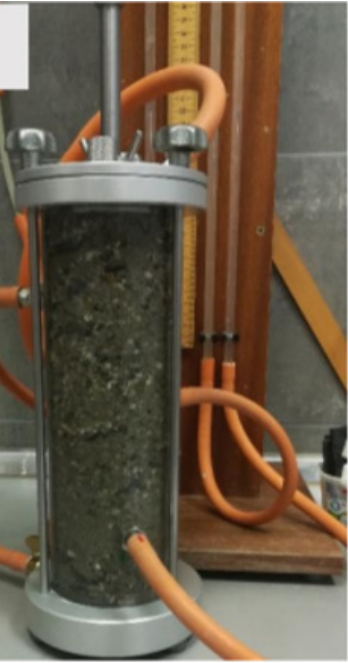

(d) sample GP

Figure 4: Saturation of samples placed in the permeameter (Živković, 2020)

soil permeability in comparison with uniformly graded gravel (GU) (Živković, 2020).

\subsection{Constant head permeameter test}

The constant head permeameter method is usually used for materials with higher permeability. The experiments were carried out in accordance with the standard ASTM: D 2434-19. Grains larger than $19 \mathrm{~mm}$ must be removed from the sample prior to placing the specimen into the testing cell, and it must not contain more than $10 \%$ of particles smaller than $75 \mu \mathrm{m}$. This condition was fulfilled for all test samples, which can be seen on the grain-size distribution curves in Figure 3.

Before testing the permeability, it is necessary to remove air from the sample, which is left behind in the pore space between the solid soil particles. The sample must be completely saturated in order to minimize the effects of trapped air in the pores on the permeability coefficient (Urumović, 2003). In our case, deionized water was used as a testing fluid, and our scope was to compare laboratory test results to some empirical correlations for different soil samples. In Figure 4, all four test samples are shown during the saturation process, which is carried out from

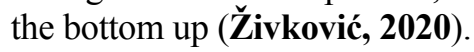

\section{Results}

\subsection{Determination of the permeability coefficient by the constant head permeameter test}

The results of determining the value of the permeability coefficient for all four samples are shown in Figure 5. The value $k$ is shown graphically as the specific rate of flow (discharge), $q(\mathrm{~m} / \mathrm{s})$ and the hydraulic gradient, $i(-)$. Based on the measured data, the lines were approximated and the values of the permeability coefficient were shown.
The values measured at low water flow rates through the sample, when laminar linear flow was achieved, are indicated by black circles in Figure 5. At higher velocities, the flow first passes from laminar linear into laminar non-linear flow and then into turbulent flow, which is marked in Figure 5 by red squares.

The values of the permeability coefficient for uniformly graded sand (SU) are $7.3 \cdot 10^{-4} \mathrm{~m} / \mathrm{s}$, for uniformly graded gravel (GU) $5.5 \cdot 10^{-2} \mathrm{~m} / \mathrm{s}$, for well graded gravel (GW) $1.5 \cdot 10^{-3} \mathrm{~m} / \mathrm{s}$ and for poorly graded gravel (GP) $5.0 \cdot 10^{-4} \mathrm{~m} / \mathrm{s}$.

For the GU sample, the largest deviation of the permeability coefficient was obtained, i.e. the smallest correlation coefficient, which is expected, because this is uniformly graded gravel with a higher porosity. Additionally, it should be noted that in this sample, laminar linear conditions were achieved in a very narrow range of gradients (up to a maximum of 0.06), while for all the other samples, such a flow regime was achieved up to gradients ranging from 1.2 to 2.6. This also means that tests of uniformly graded gravel samples in the permeameter should be carried out carefully over a very narrow range of gradients.

By comparing the results for three gravel samples, permeability coefficients were obtained that differ by two orders of magnitude, with the expected permeability being highest for the GU sample, and decreasing for the GW and GP samples, which is the consequence of decreasing porosity, i.e. increase of the ratio of smaller grains (see Table 2).

It is interesting to note that the GP and SU samples have a permeability of the same order of magnitude, although the porosity of gravel is almost twice as big as that of sand. As can be seen on the grain-size distribution curves (see Figure 3), these are samples with a higher ratio of finer grain fractions. 


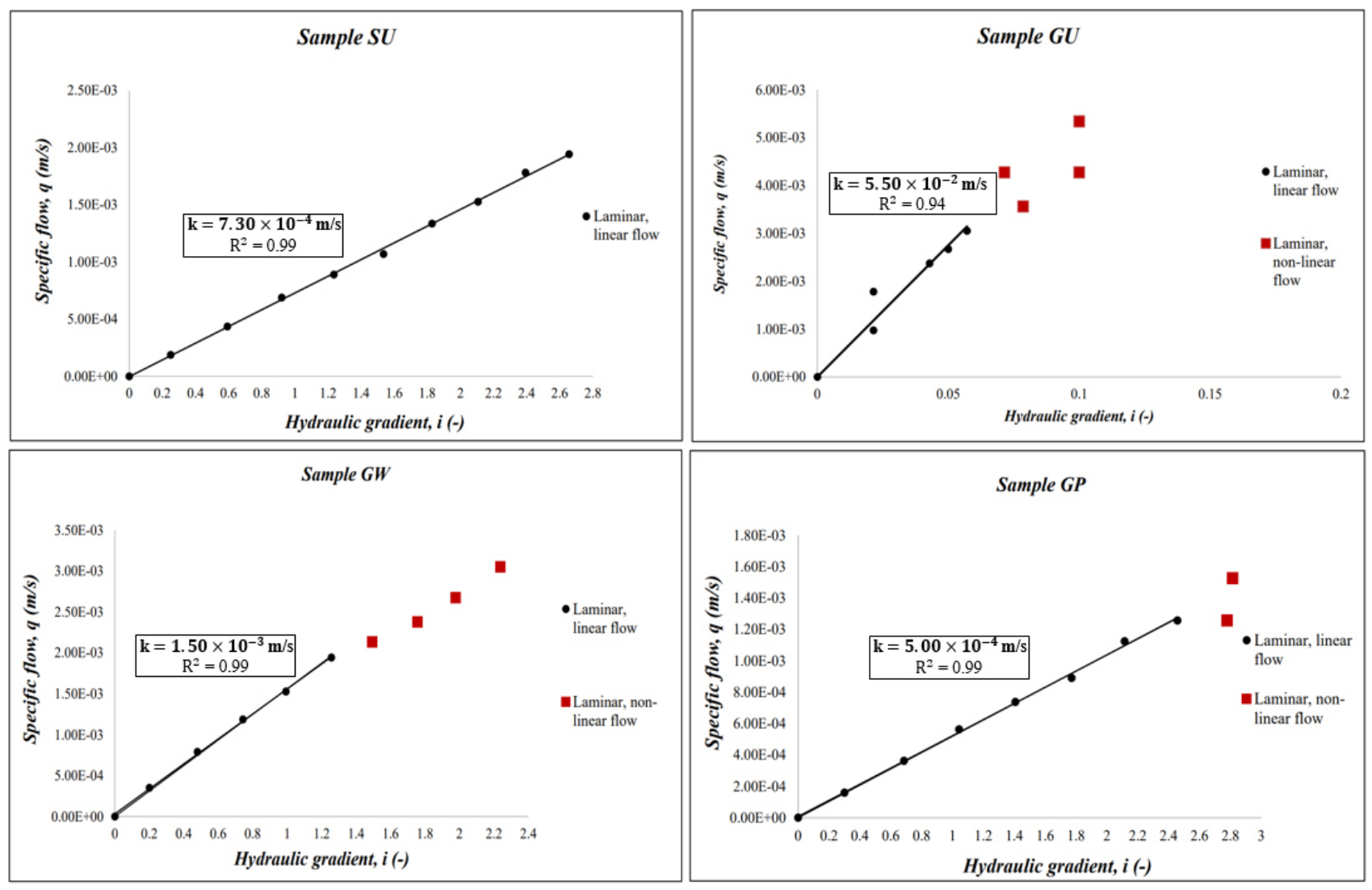

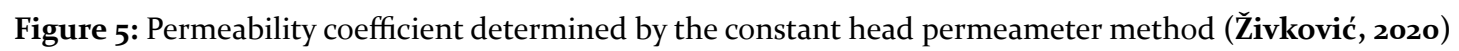

According to the obtained values of the permeability coefficient in samples GW and GP, the influence of gradation is visible, since the sizes of the maximum and minimum grains in both samples are approximately the same, and their porosity slightly differs. The values of the permeability coefficient in the mentioned samples differ by one order of magnitude (Živković, 2020).

The values of the permeability coefficient for the SU and GU samples differ by two orders of magnitude. These samples have similar ranges of the coefficient of curvature and the uniformity coefficient. By observing these two test samples, the influence of the maximum grain size on the permeability coefficient is visible. The larger the grain size, the higher the permeability of the sample (Živković, 2020), which is expected because previous research shows that with the increase of grain size the permeability coefficient increases in coarsegrained soils (Ameratunga et al., 2016).

\subsection{Estimation of the permeability coefficient by applying empirical correlations}

Based on the defined empirical correlations from Section 3.5. and the fulfilled domain of applicability, the values of the permeability coefficient shown in Table 3 were calculated and compared with the permeability coefficient obtained by direct laboratory testing. For the calculation of the permeability coefficient for all three gravel samples according to the empirical equation proposed by Barr (Devlin, 2015), the mean value of the parameter $\mathrm{C}_{\mathrm{s}}^{2}$ was determined. Gravel samples contain spherical and angular grains, so that the value of the parameter $\mathrm{C}_{\mathrm{s}}^{2}$ is 1.175 . For the sand sample, the value of the parameter $\mathrm{C}_{\mathrm{s}}^{2}$ is 1 .

By comparing the obtained results with the expected values for certain soil types found by reviewing the literature, it is shown that all the results are within the expected range. Bačani (2006) states that the values of the permeability coefficient for gravel range from $10^{-4}$ to $10^{-2} \mathrm{~m} / \mathrm{s}$, and for sand from $10^{-7}$ to $10^{-4} \mathrm{~m} / \mathrm{s}$.

The largest deviation of the estimated permeability coefficients obtained by applying empirical correlations is observed for the sample of uniformly graded sand, SU (marked in gray). The values obtained by using Alyamani and Sen and USBR correlations differ by two orders of magnitude from those obtained by direct laboratory testing. For the remaining three gravel samples, the values are similar or differ by one order of magnitude. The most similar results obtained by empirical and laboratory methods are marked in green.

Unlike Terzaghi's empirical equation, which could not be applied to the calculation of the permeability coefficient for any of the four prepared samples because they do not meet the domain of applicability. However, with the empirical equations like Alyamani and Sen, 
Barr, Chapuis and Kozeny-Carman, it was possible to calculate the permeability coefficient for all the samples, because these equations have a wide range of applica-

Table 3: Summary of the permeability coefficient obtained by empirical correlations and testing

\begin{tabular}{|l|l|l|l|l|}
\hline $\begin{array}{l}\text { Correlation/ } \\
\text { Sample }\end{array}$ & $\begin{array}{l}\mathbf{S U} \\
{[\mathbf{m} / \mathbf{s}]}\end{array}$ & $\begin{array}{l}\text { GU } \\
{[\mathbf{m} / \mathbf{s}]}\end{array}$ & $\begin{array}{l}\text { GW } \\
{[\mathbf{m} / \mathbf{s}]}\end{array}$ & $\begin{array}{l}\text { GP } \\
{[\mathbf{m} / \mathbf{s}]}\end{array}$ \\
\hline $\begin{array}{l}\text { Alyamani and } \\
\text { Sen }\end{array}$ & $7.51 \cdot 10^{-6}$ & $5.68 \cdot 10^{-3}$ & $1.87 \cdot 10^{-4}$ & $1.36 \cdot 10^{-4}$ \\
\hline & $7.60 \cdot 10^{-5}$ & $6.20 \cdot 10^{-2}$ & $5.76 \cdot 10^{-4}$ & $1.73 \cdot 10^{-4}$ \\
\hline Beyer & $1.11 \cdot 10^{-4}$ & - & $2.35 \cdot 10^{-3}$ & - \\
\hline Chapuis & $1.64 \cdot 10^{-4}$ & $3.11 \cdot 10^{-2}$ & $7.99 \cdot 10^{-4}$ & $3.12 \cdot 10^{-4}$ \\
\hline Hazen & - & $1.05 \cdot 10^{-1}$ & - & - \\
\hline $\begin{array}{l}\text { Kozeny } \\
- \text { Carman }\end{array}$ & $3.31 \cdot 10^{-4}$ & $1.09 \cdot 10^{-1}$ & $1.02 \cdot 10^{-3}$ & $1.79 \cdot 10^{-4}$ \\
\hline Sauerberi & $1.26 \cdot 10^{-4}$ & - & - & - \\
\hline Seelheim & $1.53 \cdot 10^{-3}$ & - & - & - \\
\hline Slichter & - & $3.62 \cdot 10^{-2}$ & $4.29 \cdot 10^{-4}$ & $1.36 \cdot 10^{-4}$ \\
\hline Terzaghi & - & - & - & - \\
\hline USBR & $5.28 \cdot 10^{-6}$ & - & - & - \\
\hline $\begin{array}{l}\text { Measured } \\
\text { (Constant head } \\
\text { permeameter } \\
\text { method) }(\mathrm{m} / \mathrm{s})\end{array}$ & $7.30 \cdot 10^{-4}$ & $5.50 \cdot 10^{-2}$ & $1.50 \cdot 10^{-3}$ & $5.00 \cdot 10^{-4}$ \\
\hline
\end{tabular}

tions. The other correlations listed in Table 3 could be applied to one to two samples.

Although generally most widely applicable, of the empirical equations Kozeny-Carman, Chapuis, Barr and Alyamani and Sen, for the tested samples, the best match with laboratory results was found for the Kozeny-Carman and Chapuis equations. Alyamani and Sen's equation provides the best match for the GP sample, while for GU and GW they differ by one and for the SU sample even by two orders of magnitude, which is also the largest difference observed by comparing laboratory results with those obtained by applying correlations. Barr's empirical equation provides the best match of results with the laboratory method in the case of the GU and GP samples, while in the case of the SU and GW samples, the obtained values differ by one order of magnitude. It is also interesting to note that only for the GP sample, all correlations, whose application condition was met, gave the same order of permeability coefficient values as the laboratory test.

The Sauerberi and Seelheim empirical equation can only be used for the sand sample, where a satisfactory value of the permeability coefficient was obtained. The largest deviation from laboratory results was found for the USBR and Alyamani and Sen methods for the SU sample.

The calculation by the Slichter method, according to the defined conditions, is possible for all gravel samples,

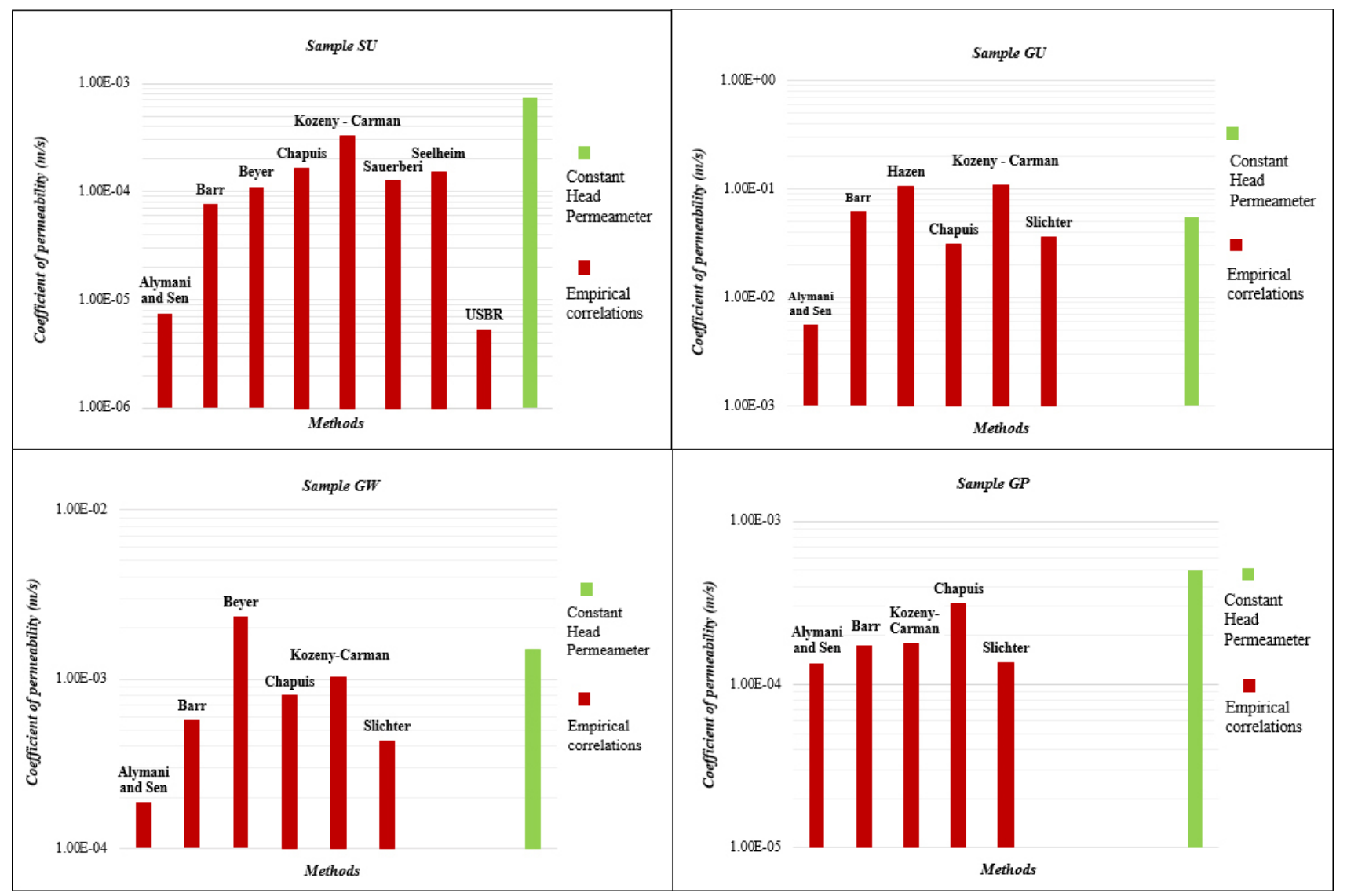

Figure 6: Comparison of permeabilities obtained by the constant head permeameter method and empirical correlations 
with a better match of calculated and measured values for the GU and GP samples.

The Breyer method is applicable to the SU and GW samples, and the results are of the same order of magnitude as the laboratory ones. Hazen's formula is applicable only to the GU sample, but the permeability differs by one order of magnitude from the one obtained in the laboratory. The USBR method is applicable only to the SU sample, but the estimated value differs from the measured one by 2 orders of magnitude.

The Terzaghi method is not applicable to any of the four test samples, because it can only be used for the calculation of coarse sand, and the SU sample represents medium to fine-grained sand.

\section{Discussion}

By using the results shown in the previous Section in Table 3, the values of the permeability coefficient obtained by applying empirical correlations and the laboratory method are shown in Figure 6. For individual samples the permeability coefficient values are shown only for those empirical equations for which it was possible to calculate $k$ with respect to the domain of applicability.

In Figure 6 the values of the permeability coefficient obtained by empirical correlations are shown in red, whereas the values obtained in laboratory tests are shown in green.

Figure 6 shows that in certain types of soil with a higher content of medium to fine sand particles, empirical equations provide smaller values compared to those obtained by the constant head permeameter method. By applying correlations for samples with a higher content of large soil particles, lower values are generally obtained in relation to the measured ones.

For the SU sample, as many as eight correlations can be applied. Two correlations do not render the same order of magnitude of the permeability coefficient, and of the other six, the most accurate estimate is the one of the Kozeny-Carman correlation. The largest deviation occurs with the USBR and Alyamani and Sen methods, in which case the value differs by two orders of magnitude.

For the GU sample, most empirical equations give a good estimate of the permeability coefficient, but the Alayman and Sen method provides a permeability that differs by one order of magnitude from the one measured in the laboratory.

For the GW sample, it was possible to calculate permeability by using six empirical equations with satisfactory domains of applicability. The Alayman and Sen method provided the largest deviation of the permeability coefficient in contrast to the one obtained by the permeameter method, while Beyer's empirical equation was most similar to the laboratory test result.

In the case of the GP sample, the values of the permeability coefficient of the same order of magnitude were obtained by empirical equations and the laboratory method. The best match of the empirical method with the performed laboratory method was obtained using the Chapuis empirical equation.

As the grain size increases, the value of the permeability coefficient also increases proportionally. The larger the particle diameter and the smaller the fine-grained fraction, the easier the water finds its flow through the sample. The permeability coefficient value for the GU sample is higher than for the other three test samples, which is expected. According to the grain-size distribution curve, the GU sample contains larger soil particles ranging from 2 to $20 \mathrm{~mm}$, and the share of the finegrained fraction (clay and sand) equals zero. According to the grain-size distribution curve, the share of the finegrained fraction prevails in the SU and GP samples in contrast to the GW and GU samples, which also corresponds to the permeability coefficients. The value $k$ obtained by the constant head permeameter method for the SU and GP samples is of the same order of magnitude, and is similar for the GW and GU samples. In the SU and GP samples the share of the fine-grained fraction dominates - the more medium to fine sand particles there are, the lower the value of the permeability coefficient. The GW sample has a smaller content of the finer fraction, and the value $k$ is more similar to the GU sample.

The present research has shown that the values obtained by applying empirical equations and direct laboratory testing can differ up to a hundred times for some soil types. Therefore, the permeability coefficient must be determined by applying several different methods, and then the design parameter must be determined on the basis of these calculations.

\section{Conclusion}

The permeability coefficient is one of the most important soil parameters for the design and construction of numerous hydrogeological, hydrotechnical, geotechnical and other works. In practical engineering, especially in hydrogeology, the permeability coefficient is often determined by empirical equations. This paper presents empirical equations from the oldest (Seelheim, Hazen) to the newest ones (Chapuis, Barr), and their applicability to different types of coarse-grained soils was investigated with direct laboratory testing of the permeability coefficient. Apart from that, the influence of grain diameter (maximum and effective) and soil gradation (well, uniformly and poorly graded) on the permeability coefficient was analysed in more detail. The constant head permeameter test was used for laboratory testing, and laboratory samples were prepared to obtain different gradations of samples and ranges of minimum and maximum grain.

Although the prepared samples met the conditions of application, by using empirical equations according to several authors, it was found that some correlations pro- 
vide a satisfactory estimate of the permeability coefficient compared to the one measured in the permeameter, but it was also discovered that some correlations differed greatly. In some cases, the difference between the measured and estimated values was two orders of magnitude based on the correlation equation. These results suggest that correlations should be applied with caution, and that at least a limited range of additional direct laboratory testing should be performed.

Generally speaking, preference should be given to field measurements of the permeability coefficient, as in this way, it is possible to cover a larger volume of soil and perform measurements in in-situ conditions, although such tests require significant financial resources and more time. The permeability coefficients are therefore much more often determined through laboratory tests and the use of empirical correlations. If we compare laboratory and empirical methods, preference should be given to laboratory determination of the permeability coefficient where the "in situ" conditions of water flow in the soil can be simulated. Our limited program of laboratory research shows that empirical correlations give satisfactory results only in some cases, although the domain of applicability has been met. The difference in values from one to two orders of magnitude can sometimes have a significant impact, especially regarding the assessment of the leakage of pollutants into the soil, or in major geotechnical constructions. In the case of assessments in the preliminary phases of a particular project, empirical methods can facilitate and speed up the process in the initial phase. Yet, they should by no means be the only method for determining the permeability coefficient in all the other project phases. In addition, the laboratory method with constant head test used in this research is only applicable to coarse-grained soils. However, permeability coefficient tests can be performed in the laboratory for all other soil types, and with the application of appropriate parameters, such as hydraulic gradients or stress conditions, these tests can provide data on the variability of the permeability coefficient that correspond to in-situ conditions. Each of the mentioned methods has its advantages and disadvantages, so it is desirable to prove each design parameter using at least two methods. Often, only after using two or more methods can we be certain of the reliability of the obtained results.

\section{References}

Alyamani, M.S. and Sen, Z. (1993): Determination of hydraulic conductivity from complete grain-size distribution curves. Ground Water, 31, 4, 551-555.

Ameratunga J., Sivakugan N. and Das M.B. (2016): Correlations of Soil and Rock Properties in Geotechnical Engineering. Springer, New Delhi, 24-32, 51-53, 142 p. ISSN 2364-5156

ASTM D6913 / D6913M-17 (2017): Standard Test Methods for Particle-Size Distribution (Gradation) of Soils Using
Sieve Analysis, ASTM International, West Conshohocken, PA, www.astm.org, 34 p.

ASTM D2434-19 (2019): Standard Test Method for Permeability of Granular Soils (Constant Head), ASTM International, West Conshohocken, PA, www.astm.org, 6 p.

Bačani, A. (2006): Hydrogeology I. Textbooks of the University of Zagreb, Faculty of Mining, Geology and Petroleum Engineering. Printing office Zelina d.d., Sveti Ivan Zelina, 62-64 p. (In Croatian) ISBN 953-6923-06-8

Boadu, F. K. (2000): Hydraulic conductivity of soils from grain-size distribution: New models. Journal of Geotechnical and Geoenvironmental Engineering, 126, 8, 739-746.

Cirpka, O.A. (2003). Environmental Fluid Mechanics I: Flow in Natural Hydro systems. Journal of Hydrology, 283, 53-66.

Das, B. M. (2010): Principles of geotechnical engineering. Cengage Learning, Stamford, 161-162 p. ISBN-10: 0-49541130-2

Devlin, J.F. (2015): HydrogeoSieveXL: An Excel-based tool to estimate hydraulic conductivity from grain-size analysis. Hydrogeology Journal, 23, 4, 837-844.

Domitrović, D., Vučenović, H. and Kovačević Zelić, B. (2012): Characterization of bentonite for engineered barrier systems in radioactive waste disposal sites. The Mining-Geology-Petroleum Engineering Bulletin (Rudarskogeološko-naftni zbornik), 24, 1, 19-27. (in Croatian)

Hazen, A. (1892): Some physical properties of sands and gravels. Massachusetts State Board of Health, Annual Report, 539-556 p.

Kovačević Zelić, B., Domitrović, D. and Veinović, Ž. (2007): Laboratory testing of bentonite clays for landfill design and construction. The Mining-Geology-Petroleum Engineering Bulletin (Rudarsko-geološko-naftni zbornik), 19, 1, 99-110. (in Croatian)

Lambe, T.W and Whitman, R.V. (1979): Soil mechanics. John Wiley and Sons, New York, 281-292 p. ISBN-10: 047 1022616

Nonveiller, E. (1979): Mehanika tla i temeljenje građevina. Školska knjiga, Zagreb, 50-57 p. (in Croatian) ISBN: 86039964589788603996456

Odong J., (2007): Evaluation of Empirical Formulae for Determination of Hydraulic Conductivity based on GrainSize Analysis. The Journal of American Science, 3(3), 1, 54-60.

Posavec, K., Kukolja, A. and Kocijan, V. (2018): Constant head permeameter tests for hydraulic conductivity of unconsolidated sediments and associated terminology, 2nd Croatian scientific congress from geomathematics and terminology in geology, Zagreb, 1-14 p.

Petrinjek I., Štuhec D., Jeftić G. and Strelec S. (2018): Comparison of different methods for determining the coefficient of permeability of non-cohesive soil. Environmental Engineering, 5, 1-2, 99-108. (in Croatian)

Preene, M and Powrie, W (2019): Assessment of permeability for design of groundwater control systems. Proceedings of the XVII ECSMGE, Geotechnical Engineering: Foundation of the Future, Reykjavik, Iceland, September 2019. $1-8$. 
Ř́ha, J. Petrula, L., Hala, M. and Alhasan, Z. (2018): Assessment of empirical formulae for determining the hydraulic conductivity of glass beads. Journal of Hydrology and Hydromechanics, 66, 3, 337-347.

Ružičić, S., Mileusnić, M. and Posavec, K. (2012): Building Conceptual and Mathematical Model for Water Flow and Solute Transport in the Unsaturated zone at Kosnica Site. The Mining-Geology-Petroleum Engineering Bulletin (Rudarsko-geološko-naftni zbornik), 25, 1, 21-31.

Ružičić, S., Kovač, Z. and Tumara, D. (2018): Physical and chemical properties in relation to soil permeability in the area of the Velika Gorica well field. The Mining-GeologyPetroleum Engineering Bulletin (Rudarsko-geološkonaftni zbornik), 33, 2, 73-82.

Salarashayeri. A.F. and Siosemarde M., (2012): Prediction of Soil Hydraulic Conductivity from Particle-Size Distribution. World Academy of Science, Engineering and Technology International Journal of Geological and Environmental Engineering, 6, 1, 16-20.

Skrzeczkowska, M. and Pietrzykowski, P. (2012): Considerations on soils isolative properties for siting of a new nearsurface radioactive waste repository in Poland in the light of the long term safety. The Mining-Geology-Petroleum Engineering Bulletin (Rudarsko-geološko-naftni zbornik), 24, 1, 101-104.

Shepherd, R.G. (1989): Correlations of hydraulic conductivity and grain size. Ground Water, 27, 5, 633-638.
Slichter C.S. (1899): Theoretical investigation of the motion of ground waters. U.S. Dept. of the Interior, Geological Survey, Water Resources Division, Ground Water Branch, Washington, D.C., 295-384 p.

Terzaghi K. (1925): Principles of soil mechanics: I-Phenomena of cohesion of clays. Engineering News-Record, $832-836 \mathrm{p}$.

Urumović, K. (2003): The physical basis of groundwater dynamics. Textbooks of the University of Zagreb. Faculty of Mining, Geology and Petroleum Engineering. Agency for Commercial Activities Ltd., Zagreb, 318 p. ISBN 9536923-01-7 (in Croatian)

Veinović, Ž., Kovačević Zelić, B. and Kvasnička, P. (2003): Advantages and disadvantages of modern laboratory measurements of the coefficient of permeability for soil materials. The Mining-Geology-Petroleum Engineering Bulletin (Rudarsko-geološko-naftni zbornik), 15, 1, 95102. (in Croatian)

Vuković M. and Soro A. (1992): Determination of hydraulic conductivity of porous media from grain-size composition. Water Resources Publications, Colorado, 83 p. ISBN - 10: 1-887201-58-0

Živković P. (2020): Comparison of the laboratory and empirical methods in determining of the coefficient of soil permeability. Master's thesis, University of Zagreb, Faculty of Mining, Geology and Petroleum engineering. (in Croatian) 


\section{SAŽETAK}

\section{Usporedba izmjerenih i procijenjenih vrijednosti koeficijenta propusnosti za umjetno pripremljene uzorke krupnozrnatoga tla}

Poznavanje koeficijenta propusnosti tla važno je u različitim znanstvenim područjima: hidrologiji i hidrogeologiji, geotehnici, geotehničkome inženjerstvu okoliša i drugim. S obzirom na različite ciljeve koje treba postići određenim inženjerskih zahvatom, prilagođavaju se uvjeti u kojima se laboratorijski određuje koeficijent propusnosti tla poput veličine hidrauličkoga gradijenta, primijenjenih naprezanja, vrste ispitnoga fluida i slično, a prilagođava se i potrebna preciznost njegove odredbe. Osim toga, koeficijent propusnosti svojstvo je tla koje ima najveći raspon mogućih vrijednosti. Moguće ga je odrediti različitim laboratorijskim i terenskim metodama te primjenom poznatih empirijskih korelacija uz korištenje podataka o granulometrijskome sastavu porozne sredine. U ovome radu prikazani su rezultati laboratorijskih ispitivanja koeficijenta propusnosti metodom sa stalnom razlikom potencijala i korištenjem permeametra te su uspoređeni s koeficijentom propusnosti dobivenim upotrebom većega broja empirijskih korelacija. Korišteni su uzorci pripremljeni u laboratoriju miješanjem različitih prethodno pripremljenih frakcija tla, kako bi se mogao utvrditi utjecaj graduiranosti tla i veličine čestica na koeficijent propusnosti tla. U radu je pokazano kako se ne može dobiti dovoljno pouzdan koeficijent propusnosti tla samo korištenjem empirijskih korelacija. Iako je područje primjene određene korelacijske veze bilo zadovoljeno, izračunani koeficijenti propusnosti u nekim slučajevima znatno su se razlikovali od onih izmjerenih u laboratoriju. Svaka od gore navedenih metoda ima svoje prednosti i nedostatke te je tek upotrebom dviju ili više metoda moguće dobiti projektni parameter tla koji je dovoljno pouzdan.

\section{Ključne riječi:}

koeficijent propusnosti, permeametar, pokus s konstantnom razlikom potencijala, empirijske korelacije

\section{Author's contribution}

This paper is based on the results of investigation for the Master's thesis of Patricia Živković (Mag. Ing. Geol.), a student at the Faculty of Mining, Geology and Petroleum Engineering, University of Zagreb. She prepared the samples, performed and analysed laboratory tests, presented data in tables and diagrams and wrote the manuscript. Mirela Burečić Šafran (Mag. Ing. Min.) participated in laboratory tests, analyses of laboratory test results, preparation of figures and calculations based on empirical methods. Biljana Kovačević Zelić (PhD, Professor, Mining Engineering and Geotechnics), the supervisor of the Master's thesis, provided the resources for the research, defined the testing programme and the research goal, participated in writing the theoretical background, the discussion of the test results, the comparison of laboratory test results and empirical calculations for the soil permeability determination. 